\title{
Regional anaesthesia: complications and techniques
}

The era of regional anaesthesia commenced a little more than 100 yr ago (1884) when Koller ${ }^{1}$ discovered the local anaesthetic properties of cocaine. That same year Halsted performed brachial plexus anaesthesia at Johns Hopkins Hospital and Henry Knapp performed the first retrobulbar block in New York. Infiltration anaesthesia became commonplace right away. Within seven years of the introduction of cocaine there were 200 reports of systemic toxicity including 13 deaths $^{2}$ and by 1924 at least 26 deaths were attributed to the systemic effects of cocaine. ${ }^{3}$ Local anaesthetic toxicity continues to be one of the most common causes of mortality and morbidity in regional anaesthesia.

In $1898 \mathrm{Bier}^{4}$ performed the first spinal anaesthetic and very soon documented the first spinal headache, a complication which has bothered patients since its inception. Although spinal anaesthesia is a revered technique amongst anaesthetists it is not always appealing to patients who sometimes associate it with paralysis. Spinal anaesthesia came under attack in the U.S. in 1950 when an eminent neurologist in Boston, Foster Kennedy, strongly inferred that spinal anaesthesia caused paralysis. 5 The allegations gained further momentum by the untimely Woolley and Row ${ }^{6}$ case in England in which two patients in adjoining operating rooms were paralyzed following spinal anaesthesia. Public opinion was so strongly opposed to spinal anaesthesia in the U.K. after this that it was only occasionally used by anaesthetists for about 30 years. Were it not for the painstaking work of Vandam and Dripps ${ }^{7}$ who performed a monumental prospective study of spinal anaesthesia this technique might have suffered a similar fate in North America. Vandam and Dripps scrutinized every aspect of spinal anaesthesia in a prospective study which involved over 10,000 patients and categorically proved that when properly performed, spinal anaesthesia was a very safe technique. Subsequent reports, involving hundreds of thousands of cases, have corroborated Vandam and Dripps' conclusions.

Since local anaesthesia was first discovered in 1884 , clinicians have succeeded in gaining access to almost every nerve in the body and each year we read reports about new approaches to regional anaesthesia. Consequently, there are numerous reports of complications involving these various nerve blocks. Each technique has unique problems but there are complications which are shared by many techniques. Complications may arise as a result of errors in the following areas: selection of patients; preparation; techniques; and perioperative management.

\section{Classification of regional anaesthesia}

Central neural blockade

Spinal

Epidural

- cervical

- thoracic

- lumbar

- caudal

Peripheral nerve blocks

Multiple nerve blocks

- Brachial plexus

- Wrist

- Ankle

- Lumbosacral

- Sciatic/femoral

- Intercostals

Single nerve blocks

Others

I.V.R.A.

Arm

Leg

Other

Sympathetic blocks

Stellate ganglion

Lumbar sympathetic

Celiac plexus

Other

Local infiltration

Miscellaneous

Interpleural nerve block

From the Department of Anaesthesia, University of Albcrta Edmonton. 


\section{Patient selection}

The scope of regional anaesthesia has increased dramatically during the past two decades. Patients who, for one reason or another, were not considered candidates for regional anaesthesia, may now qualify for a combined regional/general anaesthesia technique or may even elect to have regional anaesthesia solely for the purpose of postoperative pain relief. However, not all patients are good candidates for regional anaesthesia. Regional anaesthesia is not always successful, therefore one must always consider a contingency plan in the event of failure. Occasionally, when confronted with patients who are deemed "not fit" for general anaesthesia the anaesthetist may opt for regional anaesthesia because regional is often seen as the lesser of two evils. As a general rule, if a patient is not considered a candidate for general anaesthesia neither is he a candidate for regional anaesthesia.

Regional anaesthesia may be a viable option in patients with airway problems; however, each case must be judged on its own merits and in many cases there is a strong argument in favour of solving the airway problem first. ${ }^{8}$

Regional anaesthesia is absolutely contraindicated in very few situations, e.g., patient refusal, infection at the site of injection, and full anticoagulation. Whether one should perform regional anaesthesia in patients who are partially anticoagulated or in those who will be subsequently anticoagulated is still the subject of hot debate. $\mathrm{Rao}^{9}$ has studied this issue in depth and supports the idea of performing central neural blockade in patients who will be subsequently partially heparinized, provided these patients are carefully chosen and their clotting status is monitored closely perioperatively. There are numerous relative contraindications to regional anaesthesia, including psychiatric disorders, communicative disorders, neurological disease, cardiac disease, and sepsis. Once again each case must be judged on its merits. With proper selection of patients, potential complications of regional anaesthesia can be anticipated and avoided.

\section{Preparation of the patient}

All the necessary equipment required to administer a full general anaesthetic or carry out resuscitation must be immediately available when performing regional anaesthesia. Anaesthetists may have a false sense of security when the patient is awake: therefore, monitoring requirements may be relaxed. ${ }^{10}$ Potent narcotics and sedatives are often used prior to and during regional anaesthesia and have the potential of producing apnoea or circulatory depression when used by themselves or in combination with regional anaesthesia. There were 14 deaths associated with spinal anaesthesia in The Closed Claims Study. ${ }^{11}$ Many of these patients were young and healthy.

\section{Techniques}

General complications common to many blocks

Local anaesthetic toxicity

Neurological

Failure

Total spinal anaesthesia

Medication errors

\section{Local anaesthetic taxicity}

Local anaesthetic toxicity is one of the most common complications reported with all regional anaesthesia techniques. The following mnemonic may be useful when discussing local anaesthetic toxicity:

Allergy

Idiosyncrasy

Local

Systemic

Allergic reaction to local anaesthetics are rare and are usually associated with the ester compounds. Amide compounds are sometimes prepared with the additive methylparaben and theoretically may induce allergy. Systemic toxicity may be the logical explanation for some allergic reactions reported by patients.

Idiosyncrasy may be defined as an unusual response to a local anaesthetic injection and defies the usual explanation of predictable side-effects of local anaesthetic drugs, e.g., vasovagal attack, or hysterical reactions.

Local effects of local anaesthetics refer to effects of local anaesthetic drugs or additives on local tissue, e.g., nerve or muscle. 2-Chloroprocainc causes venous thrombosis when used for intravenous regional anaesthesia. ${ }^{12}$ Accidental subarachnoid injection of large quantities of 2-chloroprocaine-CE was linked with several cases of adhesive arachnoiditis and cauda equina syndrome during the past two decades. ${ }^{13}$ The aetiology of this syndrome is uncertain but may be related to the $\mathrm{pH}$ of the local anaesthetic or the additive sodium bisulphite. The chemical constituents of 2-chloroprocaine-CE have subsequently been altered. The new formulation of 2-chloroprocaine MPF has been associated with backache in some patients.

Systemic effects of local anaesthetic drugs account for the majority of side-effects of local anaesthetics. Dawkins $^{14}$ reported an incidence of $0.2 \%$ following epidural anaesthesia. Plevac ${ }^{15}$ reported an incidence of $1.45 \%$ following brachial plexus anaesthesia. Systemic effects most frequently occur following accidental intravascular injection of local anaesthetics and much less frequently following the injection of excessive quantities of local anaesthetics into the correct tissue plane. A number of factors influence the onset of symptoms following accidental intravascular injection. ${ }^{16}$ These include: site of 
injection; speed of injection; mass of local anaesthetic injected; cardiac output; $\mathrm{PaCO}_{2}$; pharmacological properties of the agent used and patient-related factors. A number of these factors also influence plasma levels of local anaesthetic drugs following injection into the correct tissue plane but in addition epinephrine also plays a important role.

The symptoms and signs of local anaesthetic toxicity are many and varied and include perioral numbness, tingling, auditory and visual disturbances, twitching, grand mal seizures, coma and death. When using lidocaine in adults symptoms are usually detectable when plasma levels are in excess of $6 \mu \mathrm{g} \cdot \mathrm{ml}^{-1}$ and seizures usually occur when the plasma levels exceed $10 \mu \mathrm{g} \cdot \mathrm{ml}^{-1}$ Morishima ${ }^{17}$ has shown that the dose required to produce cardiac collapse is approximately four times that required to produce convulsions in sheep. However, this ratio is less than two to one when bupivacaine is used. Bupivacaine, therefore, appears to depress cardiac activity at plasma levels not too far removed from those that cause convulsions. Bupivacaine blocks sodium channels in the cardiac cell at normal heart rates. It enters the sodium channel rapidly and tends to acccumulate giving rise to the term "fast in - slow out". In doing so, bupivacaine causes a marked depression of $V_{\max }$ and interferes with cardiac conduction leading to re-entrant arrhythmias which are difficult to manage and may be fatal. ${ }^{18}$ Ropivacaine, the s-enantiomer of bupivacaine, is currently under clinical investigation and may replace it. ${ }^{19}$ Ropivacaine has similar blocking characteristics to bupivacaine but appears to have a lesser propensity to cause cardiac toxicity.

Over the past $100 \mathrm{yr}$, hundreds of local anaesthetic drugs have been tested but a relatively small number has been used clinically. Potency goes hand in hand with toxicity. Clinicians tend to blame medications for poor outcome. With proper care and attention serious toxic effects of local anaesthetic drugs can be minimized. Local anaesthetic drugs should be administered slowly and deliberately using small quantities $(3-5 \mathrm{ml})$ at a time. Test dosing continues to be a very controversial subject. A recent study recommended using air instead of epinephrine as a marker. ${ }^{20}$ The whole concept of "test dosing" may be misleading because, in a sense, a negative test on initiation of epidural anaesthesia suggests that the catheter is in the correct tissue plane. However, there is no guarantee that the same catheter will not subsequently migrate into a blood vessel or the dura. In effect, every dose should be a test dose, and this tenet should be firmly adhered to when performing regional anaesthesia. $\mathrm{Pa}$ tients should be closely observed during and immediately after injections. Monitoring with ECG is essential when performing regional anaesthesia. One must pay particular attention when injecting local anaesthetic drugs in the head or neck region or in other highly vascular areas. As little as $2.5 \mathrm{mg}$ bupivacaine injected into the vertebral artery may cause convulsions.

The following mnemonic may be used to recall the treatment of local anaesthetic toxicity:

Stop injection

Airway

Ventilation

Evaluation of circulation

Drugs

Once the symptoms and signs of local anaesthetic toxicity become evident, one must immediately discontinue the injection and establish an airway as soon as possible. If the patient is not breathing spontaneously, every effort must be made to establish effective gas exchange. Manual ventilation of patients may be extremely difficult during a grand mal seizure. It may be necessary to administer succinylcholine to facilitate manual ventilation of the lungs in these circumstances. Patients become rapidly acidotic during persistent seizure activity which may enhance the degree of local anaesthetic toxicity by increasing cerebral blood flow, intracellular ion trapping and by increasing the amount of free local anaesthetic available. One must evaluate the circulation and treat arrhythmias as they occur. Cardioversion may be necessary if ventricular tachycardia on fibrillation occurs. Recalcitrant arrhythmias induced by bupivacaine may be treated with bretylium $5 \mathrm{mg} \cdot \mathrm{kg}^{-1}$ iv up to a maximum of $10 \mathrm{mg} \cdot \mathrm{kg}^{-122}$

\section{Neurological complications}

Permanent neurological injury is fortunately a rare occurrence in regional anaesthesia. Lund ${ }^{23}$ gathered data on over 200,000 spinal anaesthetics between 1947 and 1967, and reported no cases of permanent neurological sequelae. Noble et al. ${ }^{24}$ presented data involving about 80,000 spinal anaesthetics in Canada between 1959 and 1969 and also reported a zero incidence of permanent damage. Dawkins $^{25}$ reviewed the world literature involving epidural anaesthesia covering the years 1945 to 1969 and reported a $0.02 \%$ incidence of permanent injury. The most up to date report on permanent neurological damage following central neural blockade comes from Sweden and involved more than 500,000 patients. ${ }^{26}$ The incidence of permanent sequelae was extremely low.

The aetiology of permanent neurological injury may be categorized under the following headings:

Trauma

Chemical

Infection 
Ischaemia

Compression

Idiopathic

Transient neurological injury is far more common, however. Plevac ${ }^{27}$ and Selander ${ }^{28}$ reported the incidence of neuropraxia to be in the range of $1.9-2.2 \%$ following brachial plexus anaesthesia. Dawkins ${ }^{29}$ reported a $0.1 \%$ incidence of transient injury following epidural anaesthesia, and Vandam and Dripps reported a $0.8 \%$ incidence following spinal anaesthesia.

The Closed Claims Study in the US reviewed more than 1500 cases which had already been legally dealt with and showed that nerve injury accounted for $15 \%$ of all the closed claims injuries. ${ }^{30}$ They also showed that lumbosacral injury was clearly associated with regional anaesthesia. Although one cannot draw any major conclusions about the true incidence of neurological injury from the Closed Claims Study, it tends to confirm that permanent injuries are rare. Data from The Closed Claims Study indicate that the aetiology of nerve injury under anaesthesia was difficult to explain in a large number of cases. It was also disturbing to note that in nerve injury cases rulings were made in favour of the plaintiff in about $45 \%$ of cases even though the standard of care was met.

In summary, permanent neurological injury is rare and transient neurologic injury is uncommon. The aetiology of these injuries is frequently poorly understood, but the following advice is offered: use a marking pencil to determine the landmarks when performing regional anaesthesia. Use local anaesthesia freely when infiltrating. Warn patients in advance about injections. Converse with the patient during the procedure. Use small gauge needles whenever possible. If patients complain of pain during injection, discontinue the injection immediately and reposition the needle. Dogged persistence in the face of technical difficulties is foolhardy and is to be strongly discouraged. If one cannot perform spinal or epidural anaesthesia within $15 \mathrm{~min}$, one should seek help or seriously consider an alternative method unless circumstances dictate otherwise. Unless one establishes a time limit within which to perform a given block, patients are subjected to unnecessary pain and complications are more likely to occur.

\section{Failure}

Regional anaesthesia, unlike general, is somewhat less predictable. Failure rates vary with each individual block. One may expect failure rates of less than $1 \%$ with retrobulbar anaesthesia and up to $30 \%$ with brachial plexus anaesthesia. Failure rates may be reduced by proper selection of patients, timing, and the skill of the anaesthetist.

\section{Total spinal anaesthesia}

Total spinal anaesthesia may occur when a needle is inserted close to the central neuraxis and local anaesthetic drugs are injected. Total spinal anaesthesia most frequently occurs when a large quantity of local anaesthetic drug intended for the epidural space reaches the subarachnoid space. Total spinal anaesthesia may also occur when an excessive quantity of local anaesthetic drug is given during spinal anaesthesia. Obstetric patients are particularly vulnerable. Total spinal anaesthesia has also been reported following retrobulbar blocks, brachial plexus anaesthesia, sympathetic blocks and others. There are at least three mechanisms that may cause total spinal anaesthesia. ${ }^{31}$

Direct injection into the subarachnoid space;

Injection into the dural cuff region;

Intraneural injection.

Total spinal anaesthesia is characterized by a rapid onset of flaccidity, apnoea, unconsciousness and circulatory collapse. Treatment includes ventilation and circulatory support.

\section{Medication errors}

Medication errors are among the most common errors that physicians and other health personnel make in their daily practice. Anaesthesia is no exception. These errors usually involve overdose, injection of the wrong solution or injection into the wrong site. Injection of the wrong solution into the subarachnoid or epidural space may have very serious consequences, but not always. Thiopentone $^{32}$ has been injected into the caudal canal without serious sequelae. Potassium chloride ${ }^{33}$ has been injected into the epidural space causing permanent damage. The risk of medication errors may increase because catheter techniques are being used more frequently in the postoperative period.

When injecting local anaesthetic solutions it is most important to carefully read the label of the injectate. Unfortunately, a number of medications are prepared in vials which are almost indistinguishable from one another in appearance. As a general rule one should ask a second person to confirm the contents of a vial before injecting into the tissues.

\section{Specific complications}

\section{Central neural blockade}

\section{HEADACHE}

Headache is one of the most consistent complications associated with spinal or epidural anaesthesia. The incidence is influenced by the following factors: age, sex, 
and needle gauge. ${ }^{34} \mathrm{~A}$ number of other factors may influence the incidence of headache and these include: bevel orientation, ${ }^{35}$ angle of approach, and needle point. ${ }^{36}$ Numerous remedies are recommended to treat spinal headache including bed rest, abdominal binders and caffeine but the blood patch method appears to be the most reliable. ${ }^{37}$ Prophylactic blood patch has also been recommended. ${ }^{38}$

\section{HAEMODYNAMIC EFFECTS}

Hypotension is one of the most consistent complications reported during spinal and epidural anaesthesia. Moore reported an incidence of $38 \% .{ }^{39}$ A $30 \%$ decline in systolic blood pressure is associated with a decrease in cardiac output and should be treated. ${ }^{40}$ There were 14 cases of cardiac arrests reported following spinal anaesthesia in The Closed Claims Study. ${ }^{41}$ A circulatory event led to cardiac arrest in most cases. The outcome was very poor in these patients. Large doses of epinephrine may be required in the event of cardiac arrest during spinal anaesthesia.

\section{BACKACHE}

The incidence of backache is similar when one compares spinal and general anaesthesia. But the incidence is higher when one compares epidural anaesthesia with spinal or general. ${ }^{42}$ The incidence of backache in patients undergoing vaginal delivery is the same regardless of whether epidural anaesthesia was chosen or not. The most consistent factor associated with backache is the duration of the procedure not the technique of anaesthesia selected.

\section{Catheter techniques}

Catheter techniques have been in vogue for more than 50 yr. Originally, large 15-gauge urethral catheters were used for continuous spinal anaesthesia. ${ }^{43}$ These catheters have been refined over the years to the point that 32-gauge catheters are now available which may be threaded through 26-gauge needles. ${ }^{44}$ The following problems may occur with catheters:

Threading difficulties

Kinking

Occlusion

Migration (intravascular, dura, lung, spinal cord)

Knotting

Infection

Breakage

The one rule that must always be followed when handling "through-the-needle" catheters is that one must never withdraw the needle when the catheter is in place. This rule has been broken many times and, in most cases, one should not resort to surgical means of retrieval. In recent years, smaller gauge catheters have been introduced in an effort to reduce the incidence of spinal headache. Unfortunately, the sacrifice one must make in doing so is to reduce the tensile strength of the catheter; therefore, catheter breakage is more likely. Manufacturers have addressed these problems and can now make catheters that are miniscule and still maintain tensile strength.

\section{Brachial plexus anaesthesia}

\section{PNEUMOTHORAX}

The incidence of clinically significant pneumothorax is probably less than $1 \%$ following supraclavicular approaches to the brachial plexus. For this reason they are probably best avoided in outpatients.

\section{PHRENIC NERVE PARALYSIS}

The incidence of phrenic nerve paralysis with supraclavicular brachial plexus anaesthesia is in the range of $40 \%$ regardless of the approach used. ${ }^{45}$ Supraclavicular approaches to the brachial plexus are best avoided in patients with impaired respiratory function.

\section{LOSS OF PULSE}

There are at least three case reports of vascular insufficiency following the axillary approach to the brachial plexus. ${ }^{46-48}$ In view of these findings one must question the safety of deliberately transfixing the axillary artery while performing the axillary approach to the brachial plexus.

\section{Retrobulbar block}

Most of the serious complications associated with retrobulbar anaesthesia have already been alluded to under the heading "general complications." Retrobulbar haemorrhage, perforation of the globe and injury to the optic nerve are additional serious complications.

\section{IVRA}

Local anaesthetic toxicity is the major risk associated with intravenous anaesthesia. Bupivacaine is not recommended for this technique.

\section{Sympathetic blocks}

The major risks associated with sympathetic blocks have already been discussed and include local anaesthetic toxicity and total spinal anaesthesia. Each individual technique has its own specific problems.

STELLATE GANGLION BLOCK

Additional complications: Horner's syndrome; pneumo- 
thorax; recurrent laryngeal nerve block; cardiac arrest; puncture of oesophagus; phrenic nerve block; brachial plexus block; mediastinitis.

\section{LUMBER SYMPATHETIC BLOCK}

Additional complications: somatic block; hypotension; haemorrhage; infrarenal injection; neuritis.

\section{CELIAC PLEXUS BLOCK}

Additional complications: hypotension; epidural anaesthesia; haematoma formation.

\section{Miscellaneous}

\section{INTERPLEURAL BLOCK}

The interpleural technique was first described by Kvalheim and Reiestad in $1984 .{ }^{49}$ The following is a brief description of the technique: an epidural needle is inserted through the eighth intercostal space about $8-10 \mathrm{~cm}$ from the posterior midline. The needle is inserted at an angle of 30-40 degrees to the skin with the opening directed upwards towards the skin. The needle is inserted close to the upper border of the rib. The needle is attached to a well-lubricated glass airfilled syringe. As the needle perforates the parietal pleura the plunger should fall passively: the catheter is then advanced about $5 \mathrm{~cm}$ into the pleural space. The mechanism of blockade has not been clearly elucidated but is probably related to the spread of local anaesthetic solution to the paravertebral space. There are a number of indications for interpleural block. It appears to be particularly effective following cholecystectomy and renal surgery and less so following thoracotomy. The technique has also been used to treat chronic pain problems such as herpes zoster, pancreatic pain, and multiple rib fractures.

Since the technique was first reported in 1984 there have been several published reports involving more than 700 patients. ${ }^{50}$ The following is a list of some of the important complications reported in these patients: pneumothorax $2 \%$; systemic toxicity $1.3 \%$; pleural effusion/ infection $0.4 \%$. The true impact of this technique on the practice of regional anaesthesia remains to be seen. It is difficult to draw any major conclusions from the experience reported to date.

\section{Perioperative complications}

A number of additional complications occur intraoperatively or postoperatively which are directly or indirectly related to regional anaesthesia. Patients occasionally develop nausea and vomiting intraoperatively which may be related to haemodynamic changes induced by the technique or may be the direct side-effects of some of the medications used for sedation or narcosis. Urinary reten- tion is a common postoperative complication of central neural blockade. Nausea, vomiting, and pruritus are common complications of epidural and intrathecal narcotics when used to treat postoperative pain. Delayed respiratory depression is a much feared complication following spinal and epidural narcotics and there is still considerable debate about the required surveillance for these patients in the postoperative period. Healthy, obstetric patients appear to tolerate $4 \mathrm{mg}$ epimorph postoperatively following Caesarean section with little additional surveillance in the postoperative period. Acute pain therapy is a new concept of anaesthesia and is quickly replacing the age-old approach to postoperative pain management. ${ }^{51}$ The establishment of acute pain therapy requires knowledgeable anaesthetists who are willing to dedicate their time and effort to educate nurses and other health care personnel about these techniques. With increased expertise, knowledge and education these techniques will be routinely available to a larger number of patients postoperatively.

\section{Summary}

In this review an effort has been made to highlight the most common and most important complications of regional anaesthesia and the most up-to-date treatment of these problems. For more complete information one should refer to the bibliography and major textbooks on this subject.

\section{References}

1 Koller $C$. The use of cocaine for producing anaesthesia of the eye. (Translated and reprinted) Lancet $1884 ; 2$ : 990-2.

2 Woods JH, Downs DA. The psychopharmacology of cocaine. Drug use in America: problem in perspective, Appendix Vol. 1: Pattems and consequences of Drug use. Washington: U.S. Government Printing Office 1973; 116-39.

3 Mayer $E$. The toxic effects following the use of local anaesthetics. JAMA 1924; 82: 876-85.

4 Bier $A$. Experiments regarding the cocainization of the spinal cord. Zietschrift fur Chirurgie 51: 361-368; 1899. Translated in Classical file. Survey of Anesthesiology 1962; 6: 352-8.

5 Kennedy $F$, Effron AS, Perry $G$. Grave spinal cord paralyses caused by spinal anaesthesia. Surg Gynccol Obstet 1950; 91: 385-98.

6 Cope RW. The Woolley and Roe Case. Woolley and Roe versus Ministry of Health and Others Anacsthesia 1954; 9: 249-70.

7 Dripps RD, Vandam $L D$. Long term follow-up of patients who received 10,098 spinal anaesthetics. Failure to 
discover major neurological sequelae. JAMA 1954; 156: 1486-91.

8 The Experts Opine. Survey of Anesthesiology 1990; 34: 125-30.

9 Rao TLK, El-Etr AA. Anticoagulation following placement of epidural and subarachnoid catheters: an evaluation of neurologic sequelae. Anesthesiology 1981; 55: 618-20.

10 McIntyre JWR. Monitoring regional anesthesia. Int J Clin Monit Comp 1990 (in press).

11 Caplan RA, Wand RJ, Posner K. Cheney FW. Unexpected cardiac arrest during spinal anesthesia: a closed claims analysis of predisposing factors. Anesthesiology 1988; 68: 5-11.

12 Covino BG, Vassallo. Local anesthetics. Mechanisms of action and clinical use. New York, San Francisco, London. Grune and Stratton 1976.

13 Ravindran RS, Bond VK, Tasch MD et al. Prolonged neural blockade following regional anesthesia with 2-chloroprocaine. Anesth Analg 1980; 59: 447-51.

14 Massey Dawkins CJ. An analysis of the complications of extradural and caudal block. Anaesthesia 1969; 24: 554-63.

15 Plevak DJ, Lindstromberg JW, Danielson DR. Paresthesia vs nonparesthesia - the axillary block anesthesiology 1983; 59: A216.

16 Scott $D B$. Toxic effects of local anaesthetic agents on the central nervous system. Br J Anaesth 1986; 58: 732-5.

17 Morishima HO, Pederson H, Finster $M$ et al. Is bupivacaine more cardiotoxic than lidocaine? Anesthesiology 1983; 59: A409.

18 Clarkson $C W$, Hondeghem LM. Mechanism for bupivacaine depression of cardiac conduction: fast block of sodium channels during the action potential with slow recovery from block during diastole. Anesthesiology 1985; 62: 396-405.

19 Scott $D B$, Lee A, Fagan $D$ et al. Acute toxicity of ropivacaine compared with that of bupivacaine. Anesth Analg 1989; 69: 563-9.

20 Leighton $B L$, Norris $M C$, DeSimone $C A$ et al. The air test as a clinically useful indicator of intravenously placed epidural catheters. Anesthesiology 1990; 73: 610-3.

21 Kozody R, Ready LB, Barsa JE, Murphy TM. Dose requirement of local anaesthetic to produce grand mal seizure during stellate ganglion block. Can Anaesth Soc J 1982; 29: 489-91

22 Kasten GW, Martin ST. Bupivacaine cardiovascular toxicity. Comparison of treatment with bretylium and lidocaine. Anesth Analg 1985; 64: 911-6.

23 Lund PC, Cwik JC. Modern trends in spinal anaesthesia. Can Anaesth Soc J 1968; 15: 118-34.

24 Noble AB, Murray JG. A review of complications of spinal anaesthesia with experiences in Canadian teaching hospitals from 1959 to 1969. Can Anaesth Soc J 1971; 18: 5-17.

25 Massey Dawkins CJ. An analysis of the complications of extradural and caudal block. Anaesthesia 1969; 24: 554-63.

26 Nunn JF, Utting JE, Brown Jr BR. General Anacsthesia Sth ed. London; Butterworths \& Co. Ltd. 1989; 1106-12.

27 Plevak DJ, Lindstromberg JW, Danielson DR. Paresthesia vs nonparesthesia - the axillary block. Anesthesiology 1983; 59: A216.

28 Selander $D, E d s h a g e S$, Wolff $T$. Paresthesiae or no paresthesiae: nerve lesions after axillary blocks. Acta Anaesthesiol Scand 1979; 23: 27-33.

29 Massey Dawkins CJ. An analysis of the complications of extradural and caudal block. Anaesthesia 1969; 24: 554-63.

30 Kroll DA, Caplan RA, Posner $K$ et al. Nerve injury associated with anesthesia. Anesthesiology 1990; 73: 202-7.

31 Winnie AP. Plexus Anesthesia. Philadelphia, Toronto: W.B. Saunders Co. 1983; 242-8.

32 Forrestner J. (personal communication)

33 Shanker KB, Palker NV, Nishkala R. Paraplegia following epidural potassium chloride. Anaesthesia $1985 ; 40: 45-7$.

34 Vandam $L D$, Dripps $R D$. Long-tcrm follow-up of patients who received 10,098 spinal anaesthesias. JAMA 1956; 161: 586-91.

35 Mihic DN. Postspinal headache and relationship of needle bevel to longitudinal dural fibers. Reg Anesth 1985; 10 : 76-81.

36 Ready LB, Cuplin S, Haschke RH et al. Spinal needle determinants of rate of transdural fluid leak. Anesth Analg 1989; 69: 457-60.

37 Szeinfeld $M$, Ihmeidan IH, Moser MM et al. Epidural blood patch: evaluation of the volume and spread of blood injected into the epidural space. Anesthesiology 1986; 64: 820-2.

38 Quanor H, Corby $M$. Extradural blood path - why delay? Br J Anaesth 1985; 57: 538-40.

39 Moore DC, Bridenbaugh DL. Spinal (subarachnoid) block. JAMA 1966; 195: 123-8.

40 May $L G$, Bennett A, Lane AL et al. Effect of high spinal anesthesia on the cardiac output of normal and hypertensive patients. Am J Med 1949; 7: 251-2.

41 Caplan RA, Wand RJ, Posner K, Cheney FW. Unexpected cardiac arrest during spinal anesthesia: a closed claims analysis of predisposing factors. Anesthesiology 1988; 68: 5-11.

42 Brown E. Elman DS. Postoperative backache. Anesth Analg 1961; 40: 683-5. 
43 Tuohy EB. Continuous spinal anesthesia: a new method utilizing a urethral catheter. Surg Clin N Am 1945; 25 : 834-40.

44 Hurley RJ, Lambert $D H$. Continuous spinal anesthesia with a microcatheter technique: preliminary experience. Anesth Analg 1990; 70: 97-102.

45 Farrar MD, Scheybani $M$, Nolse $H$. Upper extremity block. Effectiveness and complications. Reg Anesth 1981; 6: 133-4.

46 Merrill DG, Brodsky $J B$, Hentz $R V$. Vascular insufficiency following axillary block of the brachial plexus. Anesth Analg 1981; 80: 162-4.

47 Restelli $L$, Pineiroli $D$, Conoscente $F$ et al. Insufficient venous drainage following axillary approach to brachial plexus blockade. Br J Anaesth 1984; 56: 1051-3.

48 On B, Neuberger L, Frey HP. Obliteration of axillary artery after axillary block. Anaesthesia 1989; 44: 773-4.

49 Kvalheim $L$, Reiestad $F$. Interpleural catheter in the management of postoperative pain. Anesthesiology 1984; 61: A231.

50 Stromskag KE, Minor B, Stein PA. Side effects and complications related to interpleural analgesia: an update. Acta Anaesthesiol Scand 1990; 34: 473-7.

51 Cousins MJ, Bridenbaugh PO. Neural Blockade 2nd ed. Philadelphia: J.B. Lippincott Co. 1988; 861-83. 


\section{Anesthésie régionale: complications et techniques}

L'ère de l'anesthésie régionale a commencé il y a un peu plus de 100 ans (1884) quand Koller ${ }^{1}$ a découvert les propriétés anesthćsiques locales de la cocaïne. La même année, Halsted a effectué une anesthésie du plexus brachial à l'Hôpital Johns Hopkins et Henry Knapp le premier bloc rétro-bulbaire à New York. Depuis lors l'anesthésie d'infiltration est devenue courante. Dans les sept premières années de l'introduction de la cocaïne il y a eu 200 cas de toxicité systémique incluant 13 décès ${ }^{2}$ et en 1924 au moins 26 décès étaient attribués aux effets systémiques de la cocaïne. ${ }^{3} \mathrm{La}$ toxicité des anesthésiques locaux continue à être une des causes les plus courantes de mortalité et morbidité en anesthésie régionale.

En 1898 , Bier ${ }^{4}$ effectue la première anesthésie sousarachnoïdienne et peu de temps après a documenté la première céphalée rachidienne, une complication qui ennuie des patients depuis les tous débuts. Même si l'anesthésie sous-arachnoïdienne est une technique très populaire chez les anesthésistes elle n'est pas toujours attrayante pour les patients qui l'associent à l'occasion avec la paralysie. L'anesthésie sous-arachnoïdienne a été décriée aux États-Unis en 1950 quand un éminent neurologue de Boston, Foster Kennedy, a impliqué sérieusement l'anesthésie sous-arachnoïdienne comme cause de paralysie. ${ }^{5}$ Ces allégations ont par la suite été renforcées par le cas Woolley et Row ${ }^{6}$ en Angleterre dans lequel deux patients dans des salles d'operation contigues sont devenus paralysés à la suite d'anesthésie sous-arachnoïdienne. L'opinion publique était tellement opposée à l'anesthésie sous-arachnoïdienne dans le Royaume Unis après cet épisode qu'elle n'a été utilisée qu'occasionnellement par les anesthésistes pour environ 30 ans. N'eut été du long et difficile travail de Vandam et Dripps ${ }^{7}$ qui ont fait une monumentale étude prospective de l'anesthésie sousarachnoïdienne, cette technique aurait subi un sort semblable en Amérique du Nord. Vandam et Dripps ont scruté chaque aspect de l'anesthésie sous-arachnoïdienne dans une étude prospective qui comprenait au delà de 10000 patients et ils ont démontré catégoriquement que quand elle est administrée correctement, l'anesthésie sousarachnoïdienne est une technique très sécuritaire. Des études subséquentes, qui impliquaient des centaines de milliers de cas ont corroboré les conclusions de Vandam et Dripps.

Depuis que l'anesthésie locale a été découverte en
1884 , les cliniciens ont réussi à accéder à peu près à tous les nerfs du corps humain et tous les ans nous lisons des travaux à propos des nouvelles approches de l'anesthésie régionale. Conséquemment on rapporte fréquemment des complications qui impliquent ces nombreux blocs nerveux. Chaque technique a des problèmes particuliers, mais il y a des complications qui sont partagées par plusieurs techniques. Elles peuvent survenir à la suite d'erreurs dans les domaines suivants : sélection des patients ; préparation ; technique ; et conduite périopératoire.

\section{Classification de l'anesthésie régionale}

\section{Blocs nerveux centraux}

sous-arachnoïdien

épidural

- cervical

- thoracique

- lombaire

- caudal

Blocs nerveux périphériques

bloc de nerfs multiples

- plexus brachial

- cheville

- poignet

- lombosacré

- sciatique et fémoral

- intercostal

bloc de nerfs isolés

- autres

Anesthésie intra-veineuse

bras

jambe

autre

Bloc sympathique

ganglion stellaire

ganglion sympathique lombaire

plexus celiaque

autre

\section{Infiltration locale}

Autres

bloc inter pleural 


\section{Sélection des patients}

Le champ de l'anesthésie régionale s'est accru de façon dramatique dans les deux dernières décades. Les patients qui pour une raison ou une autre n'étaient pas considérés candidats à l'anesthésie régionale, peuvent maintenant être candidats à une technique d'anesthésie combinée régionale-générale ou encore peuvent choisir l'anesthésie régionale uniquement pour leur analgésie post-opératoire. Cependant, certains ne sont de bons candidats pour l'anesthésie régionale. L'anesthésie régionale n'est pas toujours couronnée de succès, et dès lors il faut considérer des alternatives lorsqu'il y a échec. À l'occasion, lorsqu'un patient ne semble pas être un bon candidat à l'anesthésie générale, l'anesthésiste peut choisir l'anesthésie régionale parce qu'elle semble être le moindre mal. En règle générale si un patient n'est pas jugé être un bon candidat pour l'anesthésie générale, il n'est pas non plus un candidat pour l'anesthésie régionale.

L'anesthésie régionale peut être une option viable chez les patients avec des problèmes respiratoires; cependant chaque cas doit être évalué à son mérite et souvent il est préférable de résoudre d'abord le problème respiratoire. ${ }^{8}$

L'anesthésie régionale est contrindiquée de façon absolue dans quelques situations, e.g. , le refus du patient, une infection au site d'injection, et une anti-coagulation complète. L'utilisation d'anesthésie régionale chez des patients qui sont anti-coagulés partiellement ou chez ceux qui vont être anti-coagulés par la suite, fait l'objet encore d'un débat animé. $\mathrm{Rao}^{9}$ a évalué cette question en profondeur et supporte le concept de l'anesthésie régionale centrale chez des patients qui par la suite seront partiellement paralysés, à la condition que ces patients soient bien choisis et que leur coagulation soit suivie de près dans la période périopératoire. Il y a de nombreuses contre-indications relatives à l'anesthésie régionale, qui incluent les problèmes psychiatriques, les problèmes de communication, les maladies neurologiques, les maladies cardiaques et l'infection. Une fois de plus chaque cas doit être évalué au mérite. Avec une sélection appropriée de patients, les complications potentielles de l'anesthésie régionale peuvent être anticipées et évitées.

\section{Préparation du patient}

Tout l'équipement requis pour administrer une anesthésie régionale ou une réanimation doit être disponible instantanément lorsque l'on fait une anesthésie régionale. Les anesthésistes peuvent avoir un faux sens de sécurité lorsque le patient est éveillé et ainsi diminuer les normes de surveillance. ${ }^{10}$ Des narcotiques puissants ainsi que des sédatifs sont souvent utilisés avant et pendant l'anesthésie régionale et ont le potentiel de produire de l'apnée et de la dépression circulatoire lorsqu'utilisés par eux-même ou en combinaison de l'anesthésie régionale. Il y a eu 14 décès associés à l'anesthésie sous-arachnoïdienne dans la «Closed Claims Study » américaine de 1988.

\section{Toxicité des anesthésiques locaux}

La toxicité des anesthésiques locaux est l'une des complications les plus courantes rapportées après anesthésie régionale. Une discussion sur la toxicité des anesthésiques locaux peut s'articuler autour de la liste mnémonique suivante :

allergie

idiosyncrasie

locale

systémique

Les réactions allergiques aux anesthésiques locaux sont rares et habituellement associées aux esters. Le méthylparaben additionné occasionnellement aux amides peut en theorie induire de l'allergie. Une toxicité systémique peut être l'explication logique de quelques réactions allergiques rapportés par des patients.

L'idiosyncrasie peut être définie comme étant une réponse inhabituelle à des injections d'anesthésiques locaux et s'écarte de loin des effets secondaires prévisibles des anesthésiques locaux, e.g., réactions vasovagales ou réactions hystériques.

Les effets locaux des anesthésiques locaux font référence à leurs effets ou à ceux des additifs sur le tissus local c'est-à-dire les nerfs ou muscles. La 2-chloroprocaïne amène de la thrombose veineuse lorsqu'elle est utilisée pour l'anesthésie régionale intra-veineuse. ${ }^{12} \mathrm{~L}$ 'injection sous-arachnoïdiene accidentelle d'un volume important de 2-chloroprocaïne a été mis en cause dans plusieurs cas d'arachnoïdite et de syndrome de la queue de cheval pendant les deux dernières décades. ${ }^{13}$ L'étiologie de ce syndrome est incertain mais peut être relié au $\mathrm{pH}$ de la solution ou à l'addition de la bisulphite de sodium. Des maux de dos chez certains patients ont été associés à la nouvelle formulation de 2-chloroprocaïne MPF.

Les effets systémiques des anesthésiques locaux rendent compte de la majorité des effets secondaires des anesthésiques locaux. Dawkins ${ }^{14}$ rapporte une incidence de $0,2 \%$ d'effets systémiques à la suite d'anesthésie épidurale. Plevac ${ }^{15}$ mentionne une incidence de $1,45 \%$ à la suite de blocs du plexus brachial. Les effets systémiques les plus fréquents se produisent à la suite d'injection intra-vasculaire d'anesthésiques locaux et beaucoup moins souvent à cause d'injections de quantité excessive d'anesthésique locaux dans le bon plan tissulaire. Un certain nombre de facteurs influence le début des symptômes qui surviennent à la suite d'injection intravasculaire. ${ }^{16}$ Ceux-ci comprennent : le site d'injection ; la vitesse d'injection; la masse d'anesthésique local injecté ; le débit cardiaque ; la $\mathrm{pCO}_{2}$; les propriétés pharmacologiques de l'agent utilisé et certains facteurs propres aux 
patients. Un bon nombre de ces facteurs vont aussi influencer les niveaux plasmatiques d'anesthésiques locaux retrouvés à la suite d'injection dans le bon plan tissulaire, mais en plus l'adrénaline va aussi jouer un rôle important.

Les signes et symptômes de la toxicité aux anesthésiques locaux sont nombreux et variés et vont comprendre un engourdissement péri-oral, du tinnitus, des troubles auditifs et visuels, des soubresauts, des crises de grand mal, le coma et la mort. Lorsque l'on utilise la lidocaïne chez l'adulte, ces symptômes apparaissent habituellement quand les niveaux plasmatiques sont au delà de $6 \mu \mathrm{g} \cdot \mathrm{ml}^{-1}$ et les convulsions vont apparaitre lorsque les niveaux plasmatiques dépassent $10 \mu \mathrm{g} \cdot \mathrm{ml}^{-1}$. Morishima ${ }^{17}$ a montré que la dose requise pour produire un collapsus cardio-vasculaire est à peu près quatre fois celle requise pour amener des convulsions chez le mouton. Cependant, ce rapport est moins de deux pour un quand on utilise la bupivacaïne. La bupivacaïne donc semble déprimer l'activité cardiaque à des niveaux plasmatiques qui ne sont pas très éloignés de ceux qui amènent les convulsions. La bupivacaïne bloque les canaux sodiques de la cellule cardiaque à des fréquences cardiaques normales. Elle entre rapidement dans le canal sodique et tend à s'accumuler, ce qui donne naissance au phénomène « d'entrée rapide - sortie lente » (fast in - slow out). De la sorte, la bupivacaïne cause une dépression importante de la $\mathrm{V}_{\max }$ et nuit à la conduction cardiaque, ce qui reproduit des arrythmies par ré-entrée, difficiles à traiter et possiblement fatales. ${ }^{18} \mathrm{La}$ ropivacaïne, un énantiomère de la bupivacaïne, est actuellement sous investigation clinique et pourrait probablement la remplacer. ${ }^{19} \mathrm{La}$ ropivacaïne a des caractéristiques similaires à celles de la bupivacaïne mais semble causer moins de toxicité cardiaque.

Dans les 100 dernières années, des centaines d'anesthésiques locaux ont été évalués, un très petit nombre ont été utilisés en clinique. Leur puissance va en parallèle avec leur toxicité. Les cliniciens tendent à blamer les substances pour les mauvais résultats. Cependant, on peut diminuer les effets toxiques des anesthésiques locaux en les utilisant soigneusement. Ces substances doivent être administrées lentement en utilisant de petits volumes (3 à $5 \mathrm{ml}$ ) à la fois. L'utilisation de dose-test continue à soulever beaucoup de controverse. Un travail récent recommande l'utilisation d'air plutôt que d'épinéphrine comme marqueur. ${ }^{20}$ Tout le concept des doses-test peut être trompeur, parce que dans un sens une épreuve négative lorsqu'on débute une anesthésie épidurale va suggérer que le cathéter est dans le bon plan tissulaire. Cependant, il n'y a aucune garantie que le même cathéter ne migrera pas dans un vaisseau ou dans la dure-mère. De fait, chaque dose devrait être une dose-test, et ce concept devrait être respecté à chaque fois que l'on fait de l'anesthésie régionale. Les patients devraient être mis sous observation immédiate pendant et immédiatement après les injections. La surveillance avec électro-cardiogramme est essentielle lorsque l'on fait de l'anesthésie regionale. L'on doit aussi porter une attention particulière aux injections d'anesthésiques locaux dans la tête ou la région du cou ou tout autre région richement vascularisée. Aussi peu que $2,5 \mathrm{ml}$ de bupivacaïne injectés dans l'artère vertébrale pourront amener des convulsions. ${ }^{21}$

Lorsqu'il s'agit de traiter une manifestation toxique d'anesthésiques locaux on peut penser aux items suivants : cesser l'injection

voies aériennes

ventilation

évaluation de la circulation

autres médications

Lorsque les signes et symptômes de toxicité deviennent évidents, on doit immédiatement cesser l'injection et s'assurer le plus tôt possible du contrôle des voies aériennes. Si le patient ne respire pas spontanément il faut tout faire pour assurer un échange gazeux efficace. La ventilation manuelle des patients peut être difficile pendant une crise de grand mal. Il peut dès lors être nécessaire d'administrer de la succinylcholine pour rendre plus facile la ventilation manuelle dans ces circonstances. Les patients peuvent devenir rapidement acidotiques lorsque la convulsion persiste, ce qui augmente la toxicité des substances en accentuant le débit sanguin cérébral, et en augmentant la quantité de forme libre d'anesthésiques locaux. L'on doit évaluer l'état de la circulation et traiter les arrythmies lorsqu'elles se produisent. La cardioversion peut être nécessaire s'il y a tachycardie ou fibrillation ventriculaire. Les arrythmies rebelles induites par la bupivacaïne pourront être taitées avec brétylium à raison de $5 \mathrm{mg} \cdot \mathrm{kg}^{-1}$ jusqu'à un maximum de $10 \mathrm{mg}$. $\mathrm{kg}^{-1} .22$

\section{Complications neurologiques}

Les séquelles neurologiques permanentes sont heureusement très rares en anesthésie régionale. Lund ${ }^{23}$ a recueilli des données à partir de 200000 anesthésies rachidiennes entre 1947 et 1967 , et n'a pas retrouvé de cas de séquelle neurologique permanente. Noble et al. ${ }^{24}$ ont présenté des données qui recouvrent environ 80000 anesthésie rachidiennes au Canada entre 1959 et 1969 et mentionnent aussi une incidence nulle de dommages permanents. Dawkins $^{25}$ a revu la littérature mondiale sur l'anesthésie épidurale entre les années 1945 et 1969 et démontre une incidence de $0,02 \%$ de problèmes permanents. Le rapport le plus récent sur les séquelles neurologiques consécutives à un bloc central vient de la Suède et comprend plus de 500000 patients. ${ }^{26} \mathrm{~L}$ 'incidence de séquelles permanentes est extrêmement bas. 
L'étiologie des problèmes neurologiques permanents peut être classée selon les sujets suivants :

trauma

lésions chimiques

infection

ischémie

compression

idiopathique

Les lésions neurologiques transitoires sont beaucoup plus frequentes. Plevac ${ }^{27}$ et Selander ${ }^{28}$ mentionnent que l'incidence de neuropraxie est de l'ordre de 1,9 à $2,2 \%$ à la suite de blocs du plexus brachial. Dawkins ${ }^{29}$ mentionne une incidence de $0,1 \%$ de lésions transitoires à la suite d'anesthésie épidurale et Vandam et Dripps rapportent une incidence de $0,8 \%$ de telles lésions transitoires à la suite d'anesthésie sous-arachnoïdienne.

La "Closed Claims Study" américaine a revu plus de 1500 cas avec règlement par processus légal et ont montré que les lésions nerveuses constituent $15 \%$ de toutes les lésions soumises à un tel processus. ${ }^{30}$ Ils ont aussi montré que certaines lésions lombo-sacrées étaient clairement associées avec l'anesthésie régionale. Même si on ne peut tirer de conclusions importantes à propos de l'incidence réelle de problèmes neurologiques à partir de cette étude, elle tend à confirmer que les problèmes permanents sont rares. Les donnés de cette étude de cas à règlement légal nous indique que l'étiologie des lésions nerveuses sous anesthésie est difficile à expliquer dans un très grand normbre de cas. Il est inquiétant aussi de constater que dans les cas de lésions nerveuses, les règlements ont été surtout en faveur des plaignants dans $45 \%$ des cas même si l'on a respecté les normes de qualité de soins.

En résumé, les lésions neurologiques permanentes sont rares et les lésions transitoires sont peu fréquentes. L'étiologie de ces lésions est souvent mal comprise, mais on pourrait suivre les recommandations suivantes: l'utilisation d'un crayon marqueur pour définir les points de repères lorsque l'on fait de l'anesthésie régionale. Faire une infiltration généreuse avec les anesthésiques locaux. Avertir les patients d'avance avant de faire les injections. Entretenir un contact avec le patient pendant l'intervention. Utiliser des aiguilles de petit calibre si possible. Si les patients se plaignent de douleur pendant l'injection, cesser l'injection immédiatement et replacer l'aiguille. L'entêtement lorsqu'il y a des difficultés techniques est peu recommandable et à décourager nettement. Si quelqu'un ne peut réussir une anesthésie sous-arachnoïdienne ou épidurale dans un délai de 15 minutes, il y aura lieu de demander de l'aide ou de penser à une voie alternative à moins que les circonstances ne s'y prêtent pas. Si le praticien ne se donne pas de limite de temps pour effectuer son bloc, son patient pourra être sujet à des douleurs inutiles et les complications sont plus susceptibles de survenir.

\begin{abstract}
Insuccès
Contrairement à l'anesthésie générale, l'anesthésie régionale est moins prévisible. Les taux d'échecs varient selon les blocs. On peut s'attendre à un taux d'échec de moins de $1 \%$ dans les blocs rétrobulbaires et un taux allant jusqu'à $30 \%$ lorsqu'on pense au bloc du plexus brachial. Les taux d'échecs peuvent être diminués par une bonne sélection des patients et du moment approprié, et l'habilité du praticien.
\end{abstract}

\section{L'anesthésie rachidienne totale}

L'anesthésie rachidienne totale va se produire lorsqu'une aiguille est insérée très près de l'axe nerveux central et qu'il y a injection d'anesthésiques locaux. L'anesthésie rachidienne totale va surtout se produire lorsqu'une grande quantité d'anesthésique local destiné à l'espace épidural se retrouve dans l'espace sous-arachnoïdien. L'anesthésie rachidienne totale va aussi se produire quand une quantité excessive d'anesthésiques locaux est administrée pendant l'anesthésie rachidienne. Les patientes des services d'obstétrique sont particulièrement vulnérables. L'anesthésie rachidienne totale a aussi été rapportée à la suite de blocs rétrobulbaires, de blocs du plexus brachial, de blocs sympathiques et autres circonstances. Il y a au moins trois mécanismes qui peuvent causer l'anesthésie rachidienne totale. ${ }^{31}$

Injection directe dans l'espace sous-arachnoïdien

Injection dans un manchon épidural

Injection intraneurale

L'anesthésie rachidienne totale sera caractérisée par l'installation rapide de flaccidité, d'apnée, de perte de conscience et de collapsus cardio-vasculaire. Le traitement va comprendre la ventilation et un support circulatoire.

\section{crreurs de médication}

Les erreurs de médication comptent parmi les plus courantes dans la pratique quotidienne autant chez les médecins que dans le personnel paramédical. L'anesthésie ne fait pas exception à la règle. Ces erreurs sont surtout attribuables au surdosage, à l'injection de mauvaises solutions ou d'injections aux mauvais endroits. L'injection des mauvaises solutions dans l'espace sous-arachnö̈dien ou épidural peut avoir des conséquences très importantes mais pas nécessairement. On a déjà injecté du thiopental dans le canal caudal sans séquelle importante. Par contre, l'injection de chlorure de potassium ${ }^{33}$ dans l'espace épidural a amené des dommages permanents. Le risque d'erreur d'administration de médication peut augmenter puisque les techniques avec cathéters sont utilisés de plus en plus fréquement dans la période post-opératoire. 
Lorsque l'on injecte des anesthésiques locaux il est devenu très important de bien lire les étiquettes sur les seringues. Malheureusement, un certain nombre de médications sont préparées dans des vials difficiles à distinguer d'autres vials si on se fie uniquement à l'apparence. En règle générale on devrait demander à une deuxième personne de confirmer le contenu d'un vial avant de l'injecter dans les tissus.

\section{Complications spécifiques}

\section{Bloc centraux}

\section{CÉPHALÉE}

Les céphalées sont une des complications les plus courantes de l'anesthésie épidurale ou sous-arachnoïdienne. L'incidence est influencée par les facteurs suivants : l'âge, le sexe, et la dimension de l'aiguille. ${ }^{36}$ Un certain nombre d'autres facteurs peuvent influencer l'incidence de céphalée et ceux-ci peuvent comprendre : orientation du biseau, ${ }^{35}$ l'angle d'approche, et le type de pointe d'aiguille. ${ }^{36}$ De nombreuses approches sont recomamdées pour soulager les céphalées rachidiennes, incluant le repos au lit, les bandes abdominales et la caféine mais le «blood patch» semble être la plus efficace. ${ }^{37}$ On a même suggéré de l'utiliser sur une base prophylactique. ${ }^{38}$

\section{Effets hémodynamiques}

L'hypotension est une des complications les plus courantes l'anesthésie épidurale ou rachidienne. Moore mentionne une incidence de $38 \% .{ }^{39}$ Une chute de $30 \%$ de pression systolique va être associée à une diminution de débit cardiaque et devrait être traitée. ${ }^{40}$ Il y a 14 cas d'arrêts cardiaques mentionnés à la suite d'anesthésie rachidienne dans la "Closed Claims Study ». ${ }^{41}$ Un épisode circulatoire a amené dans la plupart des cas ces arrêts cardiaques. L'issue a été désastreuse chez ces patients. Des doses importantes d'adrénaline ont été nécessaires lorsqu'il y a eu arrêt cardiaque à la suite d'anesthésie rachidienne.

\section{LOMBALGIE}

L'incidence de lombalgie est semblable si l'on compare l'anesthésie sous-arachnoïdienne et l'anesthésie générale. L'incidence est plus élevée cependant lorsque l'on compare l'anesthésie épidurale avec les deux que l'on vient de mentionner. ${ }^{42}$ L'incidence de douleur dorsale chez des patientes qui subissent un accouchement vaginal est le même, que l'on ait administré de l'anesthésie épidurale ou non. Le facteur le plus régulièrement associé à la douleur dorsale est la durée de l'intervention et non pas la technique d'anesthésie choisie.

\section{Utilisation de cathéters}

Les cathéters sont utilisés depuis plus de 50 ans. Au début on utilisait des cathéters uréthraux de calibre 15 pour l'anesthésie rachidienne continue. ${ }^{43}$ Ces cathéters ont été améliorés au cours des années et maintenant des cathéters de calibre de 32 sont disponibles, et peuvent être enfiles dans des aiguilles de calibre $26 .{ }^{44}$ Les problèmes suivants surviennent avec les cathéters :

difficulté à les passer dans les aiguilles

coudure

occlusion

migration (intra-vasculaire, dure-mère, poumon, mœlle) noud

infection

bris

La règle principale à toujours respecter lorsque l'on manipule un cathéter dans une aiguille est de toujours retirer l'aiguille quand le cathéter est en place. Cette règle a souvent été non respectée ; dans la plupart des cas on ne devrait pas les récupérer par chirurgie. Dans les dernières années de plus petits cathéters ont été utilisés pour réduire l'incidence de céphalée rachidienne. Malheureusement, on sacrifie en ce faisant la résistance à l'étirement des cathéters et dès lors ils se brisent plus facilement. Les manufacturiers se sont penché sur ces problèmes et peuvent maintenant construire des cathéters qui sont très petits et qui sont quand même capables de maintenir une force de tension respectable.

\section{Anesthésie du plexus brachial}

\section{PNEUMOTHORAX}

L'incidence de pneumothorax cliniquement pertinente est probablement de moins de $1 \%$ après des blocs supraclaviculaires. Pour cette raison ils sont à éviter probablement chez les patients ambulatoires.

\section{PARALYSIE DU NERF PHRÉNIQUE}

L'incidence de paralysie du phrénique avec le bloc supra-claviculaire est de l'ordre de $40 \%$ quelle que soit l'approche utilisée. ${ }^{45}$ Les approches supra-claviculaires du plexus brachial sont a éviter chez les patients avec problèmes respiratoires.

\section{PERTE DE POULS}

On a rapporté au moins trois cas d'insuffisance vasculaire à la suite de blocs du plexus brachial par voie axillaire. ${ }^{46-48}$ Devant ces faits il faut se poser des questions sur le danger de transfixer de façon délibérée l'artère axillaire lorsqu'on fait un bloc du plexus brachial par voie axilliaire.

\section{Bloc rétro-bulbaire}

La plupart des complications importantes rapportés avec l'anesthésie rétro-bulbaire ont déjà été mentionnées sous 
le chapitre des complications générales. L'hémorragie rétro-bulbaire, la perforation du globe et les blessures aux nerfs optiques sont des complications sérieuses supplémentaires.

\section{Bloc intra-veineux}

La toxicité des anesthésiques locaux constitue le risque le plus important associé à l'anesthésie intra-veineuse. On ne recommande pas l'utilisation de la bupivacaïne pour cette technique.

\section{Bloc sympathique}

Les risques importants associés aux blocs sympathiques ont déjà été mentionnés et comprennent la toxicité des anesthésiques locaux et l'anesthésie rachidienne totale. Chaque technique particulière a ses propres problèmes.

\section{BLOC STELLAIRE}

Il y a des complications additionnelles: syndrome de Horner; pneumothorax ; bloc du nerf récurrent laryngé ; arrêt cardiaque ; ponction de l'œsophage; bloc du nerf phrénique ; bloc du plexus brachial ; médiastinite.

\section{BLOC SYMPATHIQUE LOMBAIRE}

Autres complications rapportées : bloc somatique; hypotension; hémorragie ; injection intra-rénale; névrite.

\section{BLoC DU PLEXUS CELLIAQUe}

Autres complications: hypotension; anesthésie épiduraie; formation d'hématome.

\section{Autres blocs}

\section{BLOC INTERPLEURAL}

La technique de bloc interpleural a d'accord été décrite par Kvalheim et Reiestad en $1984 .{ }^{49}$ Voici une brève description de la technique : une aiguille épidurale est introduite par le huitième espace intercostal environ 8 à $10 \mathrm{~cm}$ de la ligne postérieure. L'aiguille est inséré à un angle de 30 à $40^{\circ}$ par rapport à la peau avec son ouverture dirigée vers le haut et vers la pcau. L'aiguille passe près de la partie supérieure de la côte. L'aiguille est fixée à une seringue de verre remplie d'air. Lorsque l'aiguille perfore la plèvre pariétale, le cylindre de la seringue devrait tomber de façon passive : le cathéter est ensuite avancé d'environ $5 \mathrm{~cm}$ dans l'espace pleural. Le mécanisme du bloc n'est pas clairement compris mais est probablement relié à la diffusion de l'anesthésique local vers l'espace para-vertébral. Il y a bon nombre d'indications pour le bloc intra-pleural. Il semble efficace à la suite de cholécystectomie et de chirurgie rénale mais moins lorsqu'il s'agit de thoracotomie. Cette technique a été utilisée aussi pour traiter des problèmes de douleur chronique telle que l'herpès, la douleur pancréatique, et les fractures de côtes multiples.
Depuis que la technique a été rapportée en 1984, il y a eu de nombreuses publications qui impliquaient plus de 700 patients. ${ }^{50} \mathrm{La}$ liste suivante mentionne quelques unes des complications importantes rapportées chez ces patients: pneumothorax, $2 \%$; toxicité systémique $1,3 \%$; effusion pleurale ou infection $0,4 \%$. L'impact rél de cette technique sur la pratique de l'anesthésie régionale demeure à établir. Il est difficile de tirer des conclusions importantes à partir de l'expérience recueillie à date.

\section{Complications périopératoires}

Certaines autres complications reliées directement ou indirectement à l'anesthésie régionale peuvent se produire pendant l'intervention ou à la période post-opératoire. Certains patients vont avoir à l'occasion des nausées et des vomissements per-opératoires qui peuvent être reliés aux changements hémodynamiques causés par la technique ou être des effets secondaires directs de quelques unes des substances utilisées pour la sédation ou la narcose. La rétention urinaire est une complication peroperatoire courante des blocs centraux. Les nausées, le vomissement et le prurit sont des complications courantes des narcotiques épiduraux ou intra-thécaux utilisés pour le traitement de la douleur post-opératoire. La dépression respiratoire retardée est une complication très crainte à la suite d'utilisation de narcotiques sous-arachnoïdiens ou épiduraux et il y a beaucoup de controverse encore sur la surveillance requise chez ces patients dans la période post-opératoire. Les patientes d'obstétrique en bonne santé semblent tolérer facilement des doses de $4 \mathrm{mg}$ de morphine données après leur césarienne sans qu'il soit nécessaire de renforcir les mesures de surveillance postopératoire. Le traitement de la douleur aigüe postopératoire est un concept nouveau en anesthésie et remplace rapidement l'approche classique du traitement de la douleur post-chirurgicale. ${ }^{51} \mathrm{La}$ mise en place d'un service de la douleur post-opératoire demande la présence d'anesthésistes informés qui sont prêts à consacrer beaucoup de temps et d'efforts pour éduquer le personnel infirmier à propos de ces techniques. Avec l'accroissement de l'expertise, des connaissances et l'éducation, ces techniques deviendront disponibles de routine pour un plus grand nombre de patients en post-opératoire.

\section{Résumé}

Dans cette revue nous avons essayé de mettre en lumière les complications les plus courantes et les plus importantes de l'anesthésie régionale et d'indiquer les traitements les plus appropriés de ces problèmes. Pour des informations plus complètes l'on devrait se référer à la bibliographie et aux monographies sur le sujet.

\section{Références}

(Voir page R8) 